\title{
Litigation and the Timing of Settlement: Evidence from Commercial Disputes
}

\author{
Peter Grajzl \\ Katarina Zajc
}

CESIFO WORKING PAPER NO. 5520

CATEGORY 11: INDUSTRIAL ORGANISATION

SEPTEMBER 2015

An electronic version of the paper may be downloaded

- from the SSRN website:

- from the RePEc website:

- from the CESifo website:

WwW.SSRN.com

Www.RePEc.org

www.CESifo-group.org/wp 


\title{
Litigation and the Timing of Settlement: Evidence from Commercial Disputes
}

\begin{abstract}
Although an overwhelming proportion of all legal disputes end in settlement, the determinants of the timing of settlement remain empirically underexplored. We draw on a novel dataset on the duration of commercial disputes in Slovenia to study how the timing of settlement is shaped by the stages and features of the litigation process. Using competing risk regression analysis, we find that events such as court-annexed mediation and the first court session, which enable the disputing parties to refine their respective expectations about the case outcome, in general reduce case duration to settlement. The magnitude of the respective effects, however, varies with time. Completion of subsequent court sessions, in contrast, does not affect the time to settlement. Judicial workload affects the timing of settlement indirectly, via the effect on the timing of the first court session. We also examine the effect of other case and party characteristics.
\end{abstract}

JEL-Code: K410, K490, D020.

Keywords: dispute duration, settlement, litigation, survival analysis.

\author{
Peter Grajzl* \\ Department of Economics \\ The Williams School, Washington \& \\ Lee University \\ USA - Lexington, VA 24450 \\ grajzlp@wlu.edu
}

\author{
Katarina Zajc \\ Faculty of Law \\ University of Ljubljana \\ Slovenia-1000 Ljubljana \\ katarina.zajc@pf.uni-lj.si
}

*corresponding author

September 2, 2015

For assistance in data collection and for helpful insights we are grateful to Sebastijan Potepan and Nevenka Rihar. We thank Nina Betetto, Samantha Bielen, Libor Dušek, Aleš Galič, Wim Marneffe, Margherita Saraceno and participants at the workshop on the Economic Analysis of Litigation in Torino for valuable comments and discussion. 


\section{Introduction}

A substantial portion of legal disputes across different legal systems ends in settlement (see, e.g., Galanter 2004, Eisenberg and Lanvers 2009, Dimitrova-Grajzl et al. 2014). Accordingly, a voluminous body of literature in law and economics has explored the disputing parties' incentives to settle rather than pursue trial. ${ }^{1}$ What remains comparatively less well understood are the determinants of the timing of settlement (Fournier and Zuehlke 1996: 310; Boyd and Hoffman 2012: 901).

An understanding of factors influencing the duration of case resolution to settlement is important because litigation delays are a significant policy concern in many jurisdictions (see, e.g., CEPEJ 2014). Prolonged litigation increases private and public legal expenditures, perpetuates the uncertainty faced by the disputing parties, and leads to inter-temporal redistribution of wealth from plaintiffs to defendants. Each of these factors provides incentives for strategic litigation, which in turn further increases court backlogs, inhibits the efficiency and equity objectives of the legal system (Fenn and Rickmann 2013), and imposes demands on scarce public funds. Accordingly, one objective of legal reform has become the reduction in the costs of the legal system "by inducing more people to settle their disputes" (Farmer and Pecorino 1996: 79).

Yet due to the general scarcity of fine-grained duration data on the resolution of legal disputes, micro-level empirical analyses of the duration of litigation, and in particular the time it takes for parties to reach settlement, are scant. Studies of the timing of settlement are particularly scarce in the context of civil-law legal systems (see, e.g., Deffains and Doriat 1999, Westeus

\footnotetext{
${ }^{1}$ For an overview of the literature on litigation, see Cooter and Rubinfeld (1989), Farmer and Pecorino (1996), Hay and Spier (1998), Kaplow and Shavell (2002: Ch.5), Shavell (2004: Ch. 17-18), Spier (2007), and Daughety and Reinganum (2012).
} 
2014, Ayuso et al. 2015) where the procedural aspects of litigation, and thus the set of rules and incentives shaping settlement decisions, can differ notably from those in common-law legal systems (see, e.g., Kessler 1996, Fournier and Zuehlke 1996, Spurr 1997, Eisenberg and Farber 1997, Boyd and Hoffman 2012, Fenn and Rickmann 2013).

To empirically investigate the factors affecting the time to settlement, we analyze a novel case-level dataset on the duration of commercial disputes filed in Slovenian courts of first instance. A distinguishing feature of our dataset is the availability of information about the key procedural stages in the litigation process, including whether parties were exposed to courtannexed mediation and, importantly, the precise timing of mandatory court session meetings. Participation in mediation and mandatory court session meetings provides the disputing parties with an opportunity to refine their respective expectations about the outcome of the case. Since convergence of parties' expectations about the case outcome increases the parties' incentives to settle (see, e.g., e.g., Landes 1971, Gould 1973, Posner 1977, Shavell 1982, Priest and Klein 1984, Doornik 2014), participation in mediation and mandatory court sessions should, at least in theory, reduce the time to settlement.

Using a competing risk regression framework (see, e.g., Eisenberg and Farber 1997, Boyd and Hoffman 2012, Fenn and Rickmann 2013, Ayuso et al. 2015), we demonstrate empirically that both participation in court-annexed mediation and the completion of the first court session reduces the time to settlement, a result that echoes the findings in the existing empirical literature that has examined the role of information-revealing events in litigation (Boyd and Hoffman 2012, Fenn and Rickman 2013). We further demonstrate that the positive effect of both mediation and first court session on settlement hazard gradually decreases in magnitude with time since filing of the claim. This result is consistent with the intuition that the impact of 
information-revealing events on the prospects for settlement should be weaker once a case has not settled even long after the beginning of litigation. We also find, however, that conditional on the completion of the first court session the incidence of subsequent mandatory court sessions does not statistically significantly affect the time to settlement. We discuss why and how these results may be explained by the specific rules governing the Slovenian civil procedure as well as the behavioral theories that stress the role of emotions in litigation (see, e.g., Kaufmann and Stern 1988, Huang and Wu 1992, Cross 2000, Blumenthal 2005).

We further show that, once we control for the incidence of mandatory court sessions, neither judicial workload, as measured by the average total caseload per judge, nor court resources, as proxied by the average number of judicial advisors per judge, directly affect the time to settlement. We, therefore, do not find evidence in favor of the argument that, all else equal, overburdened judges deliberately steer the disputing parties away from the relatively more time-consuming and labor-intensive trial toward the relatively quicker and less labor-intensive settlement (see, e.g., Refo 2004, Galanter 2004, Langbein 2012, Dimitrova-Grajzl et al. 2014). However, we demonstrate that judicial workload nevertheless affects the timing of settlement indirectly, by influencing the time that elapses from the filing of the claim to the occurrence of the first court session. A policy conclusion based on our findings is that a reduction in judicial workload would reduce the waiting time for the first court session and thereby also reduce case duration to settlement. Finally, we examine how the timing of settlement varies with proxies for case complexity, the stakes of the case, parties' legal form and representation, and the number of disputing parties involved in litigation.

The rest of the paper proceeds as follows. Section 2 provides a brief institutional background on the litigation process in Slovenia. Section 3 introduces the data. Section 4 lays 
out our conceptual framework and develops our hypotheses. Section 5 discusses our empirical approach and presents the estimation results. Section 6 concludes.

\section{Institutional Background: The Litigation Process in Slovenia ${ }^{2}$}

The Slovenian legal system belongs to the continental legal tradition and has been heavily influenced by German law and legal order. Governed by the Civil Procedure Act (Zakon o pravdnem postopku), Slovenian civil procedure is thus similar to German civil procedure (see, e.g., Galič 2008, Langbein 1985).

All commercial cases (gospodarske pravdne zadeve) are heard in the eleven district courts of first instance. The general rule for court jurisdiction for commercial claims of the type we examine (see Section 3.1) is that a case should be filed either in the court of the defendant's permanent residence or, alternatively, in the court that has jurisdiction over the geographic area where the act that led to the dispute (in case of a tort) took place or where the fulfillment of the contractual obligation (in case of a contract breach) should have taken place. However, disputing parties may also select any other domestic court of substantive jurisdiction (i.e. district court) as long as the choice is made by consent, signed by both parties, and the request is filed together with the lawsuit (Zakon o pravdnem postopku, Uradni list RS, no. 26/99, articles 46-69). Furthermore, in instances when the law does not prescribe exclusive jurisdiction (as is the case, for example, in real estate disputes), the parties may also choose the adjudication venue ex ante, through an appropriate clause in the contractual agreement governing their relationship.

For cases adjudicated in district courts, the law stipulates that parties may choose to either self-represent or be represented by an attorney, a law firm, or a legal representative —a

\footnotetext{
${ }^{2}$ This overview in part draws on the discussion of aspects of the Slovenian judicial system and civil procedure in Dimitrova-Grajzl et al. (2014) and Grajzl et al. (2015).
} 
plenipotentiary — who has passed the state examination in law. In commercial disputes, representation by externally hired attorneys or law firms is common but not a rule. The English rule (loser pays principle) applies in Slovenia. The law (Zakon o odvetniški tarifi) specifies the fees to be paid by the losing party based on the value of the dispute.

A lawsuit is initiated either by the plaintiff's lawyer or the plaintiff, with a submission of a complaint to the court. Prior to the first official court session, the court may present both parties with an offer for court-annexed mediation. Court-annexed mediation has been utilized in Slovenia from the late 1990s onwards. Its usage, however, has been highly uneven across courts. Since 2010, all district courts are formally obliged to offer mediation services, with the details of implementation delegated to the courts. The courts maintain a roster of mediators. The criteria for inclusion on the roster include participation in a mediation course authorized by the Ministry of Justice. Having passed a state bar exam is not a prerequisite to serve as a mediator. Mediators are frequently attorneys and retired judges. Active judges may, and occasionally do, serve as mediators although judges cannot mediate the cases that are assigned to them for adjudication.

The decision whether to accept the court's offer and pursue court-annexed mediation ultimately rests with the disputing parties. In practice, however, the extent of persuasion by courts plays a very significant role. In particular, while any party can object to mediation, the law authorizes the court to order a party, which the court considers has unreasonably objected to mediation, to pay all or part of the other party's legal costs regardless of the outcome of the case (Zakon o alternativnem reševanju sodnih sporov, Uradni list RS, article 19). Courts and their presidents vary in their enthusiasm about mediation and the assertiveness with which they steer parties toward mediation. For example, while larger courts have separate offices for alternative dispute resolution, smaller courts do not (Galič and Hodges 2012). 
If mediation takes place and is successful, the case is both de facto and for recordkeeping purposes counted as settled in-court. If the parties do not agree to mediation or if mediation is not successful, the judge schedules the first court session of the main hearing (glavna obravnava). The initial stages of this first court session are intended to determine whether there is a possibility for the two parties to settle. If the judge and disputing parties realize that there exists no scope for settlement, the main hearing of the trial typically continues immediately.

Consistent with the inquisitorial nature of the Slovene legal system, during the trial the judge is in charge of the evidentiary process. As a result, much like in the German system, the judge "is strongly positioned to encourage a litigant to abandon a case that is turning out to be weak or hopeless, or to recommend settlement" (Langbein 1985: 832).

The law stipulates that all of the facts and documentary evidence on which the plaintiff and the defendant base their respective argument must be gathered and presented no later than the end of the first session of the main hearing. Inclusion of further evidence during subsequent court sessions is permitted only in exceptional circumstances, when parties were unable to submit evidence at the first session of the main hearing due to reasons that cannot be attributed to parties' own fault. $^{3}$

During the course of litigation, disputing parties may petition the court to appoint an expert to interpret evidence. If a disputing party petitions for a court expert, the appointment and the choice of the expert are subject to the judge's discretion (Zakon o pravdnem postopku, articles 243-256). Moreover, the party petitioning the court for appointment of an expert must cover the costs of expert's participation in advance; these costs are refunded only if the party

\footnotetext{
${ }^{3}$ See Galič (2014) for a critical discussion of the restrictions on late factual allegations and evidence in Slovenia.
} 
wins at trial. These procedural rules mitigate the concern that disputing parties might request involvement of a court expert as part of a delaying tactic. The law allows for the possibility that the court appoints an expert ex officio. Court-initiated expert appointments, however, are rare in practice.

The main hearing would, in theory, ideally be concluded within a single court session. Based on the current practice of Slovenian courts, however, the main hearing typically unfolds over a number of court sessions, each typically lasting up to a couple of hours, during which the judge interviews the disputing parties, witnesses, and experts. It is not uncommon that the court sessions would be spread out over several years since filing of the case. Indeed, the Slovenian judicial system has been plagued by substantial delays in case resolution (see, e.g., Anderson et al. 2005, Dimitrova-Grajzl et al. 2012, CEPEJ 2014).

\section{Data}

\subsection{Sample}

The subset of commercial claims covered by our dataset consists of commercial claims for compensation of damages (odškodninski spori) adjudicated in the eleven district courts in Slovenia. Commercial claims for compensation of damages are a specific sub-category of commercial disputes tracked by the official Slovenian court statistics. These claims encompass commercial torts (non-contractual disputes) as well as those commercial contractual disputes where the essence of the claim is damage compensation. Our focus on commercial claims for compensation of damages is in part dictated by the data collection constraints. Specifically, the Slovenian Supreme Court and the Information Commissioner, who granted us restricted access to the data, considered it more feasible to preserve the confidential nature of court records in the process of dataset assembly in the case of commercial claims for compensation of damages than 
in the case of other, publicly more notorious, sub-categories of commercial disputes tracked in the court statistics (such as, for instance, intellectual property, banking, insurance, unfair competition, and construction industry disputes). ${ }^{4}$ At the same time, a clear benefit of analyzing commercial claims for compensation of damages is that these disputes occur across industries and businesses and, as such, allow for ample variation in disputing parties' characteristics.

Our starting sample consisted of 800 randomly selected commercial cases for compensation of damages that were filed in Slovenian district courts during the period between January 1, 2010 and January 1, 2013 and were either resolved or still pending by July 1, 2014. ${ }^{5}$ From this starting sample we dropped cases disposed via decision on lack of jurisdiction and dismissal on procedural grounds. Of the remaining cases, we further dropped cases for which records were either incomplete or evidently erroneous.

Our final sample, therefore, consists of 662 commercial claims for compensation of damages. 564 of these 662 claims were resolved, either via settlement or via court judgment. We label a case as 'settled' if it was disposed via settlement understood narrowly as an in-court agreement on the outcome of the case signed by the disputing parties in front of a ruling judge, or if a case was withdrawn (adjourned sine die). We label a case as 'resolved via court judgment' if court judgment was issued after a completed trial or, alternatively, prior to completed trial by default judgment, via decision on admission, or via the decision of nolle prosequi. ${ }^{6} 240$ of the

\footnotetext{
${ }^{4}$ Our access to the data was restricted in that we were not allowed access to the actual court case files. Instead, the information from the court case files that we had been approved to collect was recorded for us by court personnel. This practice ensured the preservation of anonymity of disputing parties during the process of dataset assembly. In the dataset made available to us, courts and disputing parties are identifiable as nameless codes.

${ }^{5}$ The precise number of commercial cases for compensation of damages filed during this time period is unclear. We learned that, for record-keeping purposes, cases in Slovenian courts are sorted under alternative categories in a haphazard way. Any administrative errors of this type, however, should not affect the representativeness of our sample.

${ }^{6}$ The proposed categorization of different modes of case disposition into the broad notions of settlement and resolution through court judgment is consistent with the existing approaches in the empirical literature on modes of case disposition (see, e.g., Galanter 2004, Hadfield 2004, Dimitrova-Grajzl et al. 2014).
} 
564 resolved cases (43\%) were resolved via settlement. 324 of the 564 resolved cases (57\%) in our sample were resolved via court judgment. 98 cases in our dataset were still pending as of

July 1, 2014. The first column in Table 1 provides the frequency distribution of the 564 disposed cases by mode of disposition. Table 2 presents variable definitions and descriptions by groups of variables that we use in our analysis in Section 5.

\subsection{Time to Settlement and Case Duration}

Table 1 provides basic summary statistics on case duration for resolved cases that were settled as well as for cases resolved via other modes of disposition. The average duration for cases that were settled is 461 days. In-court settlements on average take longer (508 days) than adjournments sine die (404 days). Figure 1 provides the frequency distribution of the incidence of settlement by day since filing of the claim. The distribution is positively skewed, with the median duration to settlement (412 days) falling short of the mean duration to settlement (461 days) by 49 days. A non-negligible proportion of all settled cases (about 8\%) endured more than 900 days. Figure 2 plots a smoothed non-parametric estimate of the settlement hazard. Settlement hazard gradually monotonically increases for the first 750 days since filing of the claim; decreases during the next 200 days; and then again increases after about 1000 days since filing of the claim to reach maximum at about 1300 days since filing of the claim.

Among non-settlement based modes of case disposition, it on average takes 591 days to receive a court judgment. Trial-based judgments on average take longest, 621 days. The average number of days to resolution via any mode of disposition in our sample is 536 days. The patterns illustrated by Table 1 therefore confirm the concern (see, e.g., CEPEJ 2014) that the path to justice in Slovenia on average takes a long time. 


\section{The Determinants of Time to Settlement: Explanatory Variables and Hypotheses}

\subsection{Theory}

In explaining when disputing parties reach settlement versus pursue trial, rational choice theories stress the importance of parties' divergent expectations about the expected trial outcome. Early contributions to this literature, due to Landes (1971), Gould (1973), Posner (1977), and Shavell (1982), as well as subsequent model by Priest and Klein (1984), attribute divergent expectations to exogenously determined excessive optimism by one or both disputing parties. Using a nonstrategic approach, these contributions examine the parties' incentives to settle rather than pursue trial by concentrating on the existence of a range of mutually acceptable settlement offers. The model predicts that, all else equal, cases settle rather than proceed to trial when the plaintiff and the defendant hold similar expectations about the trial outcome; litigation expenses are high; and the stakes and settlement costs are low.

The exogenous beliefs-based non-Bayesian framework has the appeal of elucidating key intuitions about the unfolding of litigation (Kaplow and Shavell 2002). As a consequence, it "has...served as a foundation for empirical work on settlement" (Spier 2007: 278). However, the model does not explain the underlying reason for parties' divergent beliefs and does not clarify the structure of settlement bargaining. Accordingly, more recent literature (see, e.g., P'ng 1983, Bebchuk 1984, Nalebuff 1987, Reinganum and Wilde 1986, Spier 1992, Daughety and Reinganum 1994, Friedman and Wittman 2007) emphasizes informational asymmetries as a source of parties' divergent expectations and explicitly models settlement bargaining.

Recent behavioral theories of the litigation process augment the rational choice model by emphasizing the role of emotions (see, e.g., Kaufmann and Stern 1988, Blumenthal 2005, Lurie 2013, Huang and Wu 1992, Cross 2000). According to the behavioral approach, litigants' 
decisions in the course of litigation are as much driven by emotion as they are by rational cognition. As one experienced observer of the litigation process describes it, "[1]awyers tend to think that settlement decisions are based on logic when in fact they often involve a large emotional component" (Lurie 2013). Therefore, a theory of litigation must take into account that animosity that develops in the course of litigation often diminishes the disputing parties' interest in settlement (Lurie 2013: 169). Moreover, to the extent that disputing parties are unable to accurately predict their own respective future emotional responses to anticipated events (Blumenthal 2005), the disputing parties' decisions in the litigation process are not forwardlooking, as for example assumed by sequential bargaining models of litigation (see, e.g., Spier 1992), but rather heavily influenced by the disputing parties' emotional experience of the events in the course of litigation. To articulate our hypotheses, we draw on both the rational-choice and the emotion-augmented model of litigation.

\subsection{Explanatory Variables and Hypotheses}

Our focal explanatory variables are indicator variables for the completion of court sessions and parties' exposure to court-annexed mediation. In the context of our duration data, the variables for consecutive court sessions are discrete time-varying covariates in that they change value in a discrete fashion during the course of case adjudication. Specifically, for each of the court sessions, we define an indicator variable that equals zero before the occurrence of the event (a court session) and one after the event. The indicator variable for parties' exposure to courtannexed mediation is, in contrast, time-invariant: its value does not change during the course of adjudication. $^{7}$

\footnotetext{
${ }^{7}$ We model exposure to court-annexed mediation as a time-invariant covariate because detailed information on the timing of court-annexed mediation is not available in the underlying court files.
} 
Figure 3 illustrates, first, that the timing of court sessions varies widely across cases and, second, that delays in the time elapsed between the filing of the case and the first court session are ubiquitous. The median time to first court session is about 466 days. The first court session took place within 300 days of the filing of the case in only about $29 \%$ of the cases in our sample. In about $10 \%$ of the cases the first court session took place more than 900 days after the filing of the case. There is also substantial variation in the timing of the second, third, fourth, and even fifth court session. Among the later court sessions (in particular fourth and fifth), the earliest naturally take place after considerable time (around 300 days) has elapsed since the filing of the claim. Court-annexed mediation was introduced in $12 \%$ of the cases (see Table 3).

Mediation and participation in the first mandatory court session, by the end of which all relevant evidence must be presented (see Section 2), provide an opportunity for the parties to refine their information about the case during the course of litigation. Based on the divergent expectations theories of litigation, a reduction in the extent of divergence of parties' expectations about the expected trial outcome facilitates settlement (see, e.g., Landes 1971, Gould 1973, Posner 1977, Shavell 1982, Priest and Klein 1984, Farber and White 1991, Doornik 2014). We, therefore, hypothesize (Hypothesis 1a) that completion of the first court session and exposure to court-annexed mediation reduce the time to settlement. The relevance of information exchanged during mediation and the first court session, however, diminishes over time if the case is not settled. We thus expect (Hypothesis $1 \mathrm{~b}$ ) that any positive effect of exposure to court-annexed mediation and completion of the first court session on settlement hazard decreases with time since filing of the claim.

In contrast, the effect of the completion of subsequent court sessions on settlement hazard is, at least in theory, ambiguous. On the one hand, to the extent that existing evidence may be 
interpreted in a new light at a later stage during litigation, or new evidence about the case emerges that can be used in court after the completed first court session (see Section 2), subsequent court sessions provide an opportunity for further information revelation about the case, which facilitates settlement. On the other hand, if no settlement took place relatively soon after the first court session, subsequent court sessions may contribute to growing hostility among the disputing parties (see, e.g., Blumenthal 2005), which in turn impedes settlement. Accordingly, we expect that (Hypothesis 2) completion of subsequent court sessions may, depending on the relative strength of the unobserved information-revealing versus animositybuilding effects, either reduce or increase the time to settlement.

Our remaining covariates are all time-invariant and include the characteristics of the case, the disputing parties, and the court. The average stakes in the case (the plaintiff's initial claim) are about EUR 875,000. However, the variability of stakes across cases is large: the value of the plaintiff's initial claim exceeds EUR 1,000,000 in 48 cases (7\% of the cases in our sample) and EUR 10,000,000 in eight cases. More than one judge was in charge of case resolution in 30\% of the cases ( $1 \%$ of the cases in our sample). Judicial advisor took part in case resolution in $19 \%$ of the cases. Court experts were appointed in $10 \%$ of the cases.

Based on the exogenous-beliefs version of the divergent expectations theory of litigation, higher stakes all else equal increase parties' incentive to pursue trial (Landes 1971, Gould 1973, Posner 1977, Shavell 1982, Priest and Klein 1984). In the asymmetric information based theories of litigation, however, the effect of stakes on the prospects of trial is in general ambiguous (Farmer and Pecorino 1996); depending on the model's assumptions, stakes may either increase (Bebchuk 1984) or decrease (Nalebuff 1987) the chances of trial. Involvement of a judicial advisor and appointment of a court expert signify that a case is complex, which tends to increase 
the extent of divergence of parties' expectations about trial outcome. In addition, appointment of an expert per se extends the duration of adjudication because drafting an expert report takes time. Accordingly, we hypothesize (Hypothesis 3a) that time to settlement increases with appointment of a court expert and participation of a judicial advisor. Completion of an expert report sheds new light on the case and, therefore, reduces the degree of divergence of parties' expectations. In the absence of precise information about the timing of when the expert reports were received by the court, we hypothesize (Hypothesis $3 b$ ) that the negative effect of appointment of a court expert on settlement hazard decreases in magnitude as the number of days since filing of the claim increases and, hence, the prospects that the expert report was turned in increase.

The vast majority of cases in our sample (82\%) are cases where a single plaintiff litigates against a single defendant. Multiple parties on either plaintiff or defendant side increase the costs of negotiation. We therefore expect (Hypothesis 4) that cases with multiple parties on either plaintiff or defendant side take longer to settle than cases with a single plaintiff litigating against a single defendant.

We control for disputing parties' legal form. Most cases (32\%) in our sample are cases where all involved parties are a privately owned domestic company. About $29 \%$ of the cases involve a legal entity in public interest or a government department (for example, a ministry). ${ }^{8}$ $14 \%$ of the cases involve a sole trader enterprise, $12 \%$ a physical person, $5 \%$ a municipality and about $8 \%$ a foreign entity (either a company or a physical person residing abroad). Disputing parties may inter alia differ in terms of discount rates as well as considerations about the reputational consequences of litigation outcomes, and it is it not clear whether, and is so how,

\footnotetext{
${ }^{8}$ The precise identity of these parties is unknown to us due to the restricted-access nature of our dataset (see Section 3.1). Legal entities in public interest in Slovenia provide a wide range of services and include a broad set of either public or public-private organizations such as museums, theaters, schools, libraries, hospitals, zoos, providers of recreation services and sports organizations, and public institutes for compulsory social security services (health, pension, unemployment and disability insurance).
} 
different legal forms align with these considerations. We therefore do not have a strong a priori view on how parties' legal form might affect settlement hazard.

We also control for parties' legal representation. In $43 \%$ of the cases, all involved parties (one or more plaintiffs and one or more defendants) are represented by either an attorney or a law firm. In $52 \%$ of the cases, one or more of the parties is either self-represented or represented by a plenipotentiary who is neither an externally hired attorney nor a law firm. Selfrepresentation takes place when a party is represented by itself (in case of a physical person) or by an employee such as a managing director who is typically without a legal background. Plenipotentiaries who are neither external attorneys nor law firms include in-house lawyers and retired lawyers, retired judges, and either active or retired law professors. We group selfrepresentation and representation by a plenipotentiary under a single category because the coding of the two types of representation is confounded in the case files that were used in the assembly of our dataset. In $6 \%$ of the cases, one or more parties are represented by the public prosecutor's office. The public prosecutor's office represents the government and occasionally legal entities in public interest.

The effect of legal representation on litigation outcomes crucially depends on the structure of attorney fees. All else equal, flat fees promote settlement and hourly fees the relatively more time-consuming trial-based litigation. A variety of lawyer fee structures are used in Slovenia. Given that we do not observe contractual terms for parties' legal representation, we are agnostic about the effect of parties' legal representation status on settlement hazard.

Finally, we investigate the role of court characteristics. The average total caseload (i.e. caseload that takes into account all possible cases adjudicated at a court) per judge, measured in the year of the filing of the case, equals 690 cases. The average number of judicial advisors per 
judge at a court equals a little more than one half. Trial-based modes of case disposition typically take longer than settlements (see Table 1) and consume more resources. Consistent with the theory that both the disputing parties and the judges take into account the expected benefits and costs from alternative modes of case resolution (see, e.g., Refo 2004, Galanter 2004, Langbein 2012, Dimitrova-Grajzl et al. 2014), we hypothesize (Hypothesis 5) that, all else equal, cases are settled faster if they are adjudicated in courts where the average caseload per judge (as a proxy for judicial workload) is high or the average number of judicial advisors per judge (as a proxy for court resources) is low than if they are adjudicated in courts where the opposite is true.

\section{Empirical Approach and Results}

\subsection{Empirical Approach}

To study case duration to settlement we use survival analysis (see, e.g., Fournier and Zuehlke 1996, Kessler 1996, Eisenberg and Farber 1997, Spurr 1997, Boyd and Hoffman 2012, Fenn and Rickman 2013, Ayuso et al. 2015). Unlike standard regression methods such as ordinary least squares estimation, survival analysis allows us to, first, address the issue of skewed distribution of duration times (see Figure 1); second, mitigate sample selection bias by incorporating pending cases into the estimation; and, third, model the effect of time-varying covariates such as, for example, our indicator variables for consecutive court sessions.

A case filed at a court may be disposed either via settlement or via court judgment (see Table 1). Moreover, only one of these two modes of disposition can occur first. Settlement and court judgment are therefore competing risk events. To empirically examine the determinants of settlement timing and to characterize the likelihood of settlement over time, we therefore draw on the competing risk regression framework (see, e.g., Boyd and Hoffman 2012, Fenn and Rickman 2013, Ayuso et al. 2015). 
The empirical literature utilizing survival analysis proposes two related, yet distinct, semi-parametric modeling approaches for analysis of competing-risks data: the Cox (1972) cause-specific hazard model and the Fine and Gray (1999) subdistribution hazard model (see, e.g., Andersen et al. 2012, Noordzij et al. 2013, Cleves et al. 2010). The main advantage of using the Cox regression model for estimation of cause-specific hazards lies in easy-to-interpret hazard ratios (exponentiated coefficients) associated with the covariates (see, e.g., Andersen et al. 2012, Noordzij et al. 2013, Cleves et al. 2010). In our context, the regression parameters estimated by this method directly quantify the hazard ratios among the population of those filed cases that are actually at risk of being settled. The disadvantage of the cause-specific hazards approach is that in the presence of competing risks there no longer exists a one-to-one correspondence between the cause-specific hazard (settlement hazard) and the cumulative incidence function, that is, the probability that a case is settled by a certain day. Intuitively, in order to compute the cumulative incidence of settlement, the cause-specific hazard for the competing event (court judgment) is also needed. An unsettling implication of this lack of a one-to-one correspondence between cause-specific hazard and cumulative incidence in a competing risks setting is that a covariate may affect a given cause-specific hazard and cumulative incidence function for this same cause differently (Andersen et al. 2012, Noordzij et al. 2013).

An alternative approach to competing risk data, developed by Fine and Gray (1999), specifies subdistribution hazard (or subhazard, in short) for a particular cause (settlement). ${ }^{9}$ The appeal of the subhazards model is based on the fact that the cumulative incidence function for a particular cause (settlement) is a function of the subhazard for this particular cause only. As a result, in the subhazards model, unlike in the Cox cause-specific hazards approach, there exists a

\footnotetext{
${ }^{9}$ Subhazard function for failure from cause $i$ is defined as the rate of failure from cause $i$ at time $t$ given that either no failure from cause $i$ or, alternatively, failure from cause other than cause $i$, took place before time $t$.
} 
direct correspondence between the effect of a covariate on the subhazard for failure from a certain cause (settlement) and the effect of that covariate on the cumulative incidence function for this cause (see, e.g., Andersen et al. 2012, Noordzij et al. 2013, Cleves et al. 2010). ${ }^{10}$ The drawbacks of the subhazards model stem from the fact that the estimated subdistribution hazard ratios do not lend themselves to a natural interpretation. The reason is that the subdistribution hazard for a given cause (settlement) gives the rate of failure from that cause for subjects (cases) who have either not yet failed from that cause (i.e. have not been settled) or have already failed from another cause (court judgment). The subdistribution hazard ratio thus represents a ratio in a non-existing population, one that includes subjects that have already failed from a competing event (see, e.g., Andersen et al. 2012, Noordzij et al. 2013, Cleves et al. 2010). Accordingly, the cause-specific hazards approach is deemed particularly suitable for aetiological research where the goal is the estimation of the effect of covariates on cause-specific hazard. In contrast, the subdistribution hazard model is viewed as most appropriate for prognostic research where the object of interest is the cumulative incidence function (Andersen et al. 2012, Noordzij et al. 2013).

Since we are primarily interested in estimating the effect of covariates on settlement hazard, we use the Cox regression framework to estimate cause-specific hazard ratios for settlement for the full range of available covariates while treating cases resolved via court judgment as right-censored. Because the diagnostic tests we performed led us to reject the validity of the proportional hazards assumption that underlies the basic Cox model (see Section 5.2), we also estimate specifications based on the extended Cox model in which the effect of

\footnotetext{
${ }^{10}$ That is, a positive (negative) estimate of a coefficient on a covariate means that an increase in the covariate is associated with an increase (a decrease) in the subhazard and also an increase (a decrease) in the cumulative incidence function.
} 
covariates is permitted to vary with time. As suggested in Section 4.2 (see Hypotheses $1 \mathrm{~b}$ and $3 b)$, the effect of a subset of covariates on settlement hazard in theory indeed plausibly changes with passage of time since filing of the claim. In addition, we also fit the Fine and Gray's (1999) subdistribution hazards model to estimate the cumulative incidence function for settlement.

In all of our regressions, we base inference on heteroskedasticity-robust standard errors clustered at the level of a case to account for the dependencies that arise in the expanded data format suitable for survival analysis. Specifically, 662 cases (resolved or pending) in our sample give rise to 1,762 distinct observations where an observation is defined as a time interval during which no failure event takes place and, at the same time, there is no change in the value of any of the time-varying covariates. ${ }^{11}$

We control for year fixed effects by including a full set of dummies for the year of filing and, if applicable (for resolved cases), the year of case resolution. In a subset of specifications where we do not include the variables capturing court characteristics (see Table 2), we further include a full set of court dummies to control for any court-specific effects (such as entrenched court norms and culture) on the timing of settlement.

\subsection{Results}

Table 4 reports estimated coefficient and their standard errors from three distinct Cox model specifications. Model (1) is the basic Cox model without continuous time-varying controls but with discrete time-varying controls. A positive (negative) coefficient corresponds to hazard ratio-exponentiated coefficient-greater (smaller) than one, which in turn implies that the covariate in question increases (decreases) settlement hazard or, equivalently, decreases (increases) duration to settlement. The basic Cox model assumes that covariates have a

\footnotetext{
${ }^{11}$ This approach to data formatting is standard in survival analysis (see, e.g., Cleves et al. 2010). Estimation-wise, it is equivalent to an alternative approach whereby the data is split into time intervals of fixed length (e.g. months).
} 
proportional and constant (i.e. time invariant) effect on the hazard rate. Non-proportional hazards arise if the size of the effect of a covariate changes over time. Non-proportional hazards result in a misspecified model and can give rise to erroneous inference about the effect of covariates. We tested model (1) for the validity of the proportional hazards assumption. Both the global test based on Schoenfeld (1982) residuals, proposed by Grambsch and Therneau (1994), and the test based on the re-estimated model, where we interacted the covariates included in the basic Cox model (1) with time since filing of the claim (see, e.g., Cleves et al. 2010), rejected the null that the proportional hazards assumption holds. ${ }^{12}$

We, therefore, estimate an extended Cox model where we allow for the effect of specific covariates to vary over time. Our choice of variables to be modeled as continuous time-varying covariates was guided by both theoretical framework (see, e.g., Hypotheses $1 b$ and $3 b$ in Section 4.2) and formal statistical test. In our extended Cox model specifications (2) and (3) in Table 4 we model as continuous time-varying those covariates for which the interaction between the covariate and the time since filing of the claim was statistically significant in the model estimated for the purpose of testing the proportional hazards assumption as discussed above. We therefore interpret our results based on models (2) and (3) in Table 4 while also displaying results based on the basic Cox model (1) in Table 4. Models (1) and (2) include a full set of court dummies. In model (3), we replace court fixed effects with measures for caseload per judge and judicial advisors per judge to examine the effect of judicial workload and court resources, respectively, on the timing of settlement.

Procedural events in the course of litigation indeed affect the timing of settlement. Based on the estimates of model (2) in Table 4, relative to the scenario when the first court session has

\footnotetext{
${ }^{12}$ Detailed results are available upon request.
} 
not yet taken place, completion of the first court session all else equal increases settlement hazard nine-fold when evaluated at mean time since filing of the claim at which first court session takes place (505 days). The magnitude of the positive effect on settlement hazard, however, as hypothesized gradually decreases over time: the coefficient on the interaction between the indicator variable for completion of the first court session and time since filing of the claim is negative and statistically significant. Thus, at 900 days since filing of the claim, settlement hazard for cases for which the first court session had already been completed is only about four times the settlement hazard for cases for which the first court session has not yet taken place. Given the specifics of the Slovenian litigation process, where the initial court session is crucial for presentation of evidence, these findings are consistent, among others, with the divergent expectations theory of litigation (e.g., Landes 1971, Gould 1973, Posner 1977, Shavell 1982, Priest and Klein 1984): better information about the case increases the prospects of settlement. Furthermore, since the relevance of information revealed during earlier stages of the litigation process in general decreases over time, the impact of the first court session on settlement prospects is lower for cases that have not settled even long after the beginning of litigation.

Conditional on the first court session being completed, however, we find no statistically significant evidence that the completion of further court sessions affects settlement hazard. This result may be attributed to the rules of Slovenian civil procedure which state that disputing parties are required to present any relevant case-related evidence to the court by the end of the first court session (see Section 2). Conditional on the completion of the first court session, subsequent court sessions in general do not facilitate significant revelation of further new relevant information about the case and, therefore, facilitate settlement only to a limited extent. 
The sign of estimated coefficients associated with indicator variables for subsequent court sessions (all but one are negative) is further consistent with litigation theories that emphasize the role of emotions, and in particular growing hostility among parties, in the course of litigation (Kaufmann and Stern 1988, Blumenthal 2005, Laurie 2013: 169, 172). That is, the failure to reach settlement following the completion of the first court session plausibly escalates the feelings of animosity among disputing parties. Therefore, for cases that fail to settle early, additional interaction between the disputing parties during the subsequent court sessions plausibly decreases the prospects for settlement, thereby counteracting any positive impact on settlement prospects due to further information revelation during subsequent court sessions.

Consistent with the divergent expectations theories of litigation, we find that exposure to court-annexed mediation reduces the time to settlement, although the positive effect of mediation on settlement hazard, as anticipated, decreases with time since filing of the claim. Based on the estimates of model (2) in Table 4, relative to the cases where parties were not exposed to courtannexed mediation, exposure to court-annexed mediation all else equal increases settlement hazard by about $170 \%$ at 300 days since filing of the claim and by $70 \%$ at mean case duration time since filing of the claim (536 days; see Table 1). For cases that have been litigated for a prolonged period of time (800 days or more) without settling, the estimated effect of parties' exposure to mediation on settlement prospects actually becomes negative.

Resonating with the divergent expectations theory of litigation, case complexity, as proxied by involvement of a judicial advisor and appointment of a court expert, increases time to settlement. Based on the estimates of model (2) in Table 4, when evaluated at mean case duration time since filing of the claim, settlement hazard for cases involving a court expert is all else equal less than one tenth of the settlement hazard for cases where no expert was appointed. The 
negative effect of expert appointment on settlement hazard, however, decreases in magnitude with time since filing of the claim: the estimate of the coefficient on the interaction between the indicator variable for expert appointment and time since filing of the claim is positive and statistically significant. Thus, at 900 days since filing of the claim, settlement hazard for cases for which a court expert was appointed is all else equal only $18 \%$ lower than the settlement hazard for cases for which no expert was appointed. This finding plausibly reflects the fact that eventual availability of the report prepared by the expert sheds new light on the merits of the case, which in turn facilitates settlement.

The effect of multiple parties on either the plaintiff or the defendant side is statistically insignificant at conventional levels of statistical significance: $p$-value for the relevant coefficient equals 0.168 based on the estimates of model (2) and 0.155 based on the estimates of model (3) in Table 4. Our results thus do not provide strong evidence in favor of the hypothesis that multiplicity of parties involved in the case increases the costs of negotiation, which is in turn expected to prolong the time to settlement.

Parties' legal form does not exhibit a statistically significant effect on time to settlement. The type of parties' legal representation, however, does. Time to settlement is all else equal shorter for cases where at least one of the parties is either self-represented or represented by a plenipotentiary that is neither an attorney nor a law firm than for cases where all involved parties are represented by an attorney or a law firm. Based on the estimate of model (2), settlement hazard is all else equal more than twice as large for the former as it is for the latter types of cases. This finding is broadly consistent with the principal-agent theory of legal representation (see, e.g., Shavell 2004) that lawyers prefer to delay case resolution for reasons of personal pecuniary gains. 
Drawing on the estimates of model (3) in Table 4, judicial workload, as proxied by the average total caseload per judge, and court resources, as proxied by the average number of judicial advisors per judge, do not statistically significantly affect settlement hazard. We therefore do not find evidence in support of the theory that parties tend to settle faster in courts where judicial workload is on average higher and where, as a result, judges are more likely to prefer less labor-intensive modes of case disposition such as settlement to more labor-intensive modes such as trial-based judgment (see, e.g., Refo 2004, Galanter 2004, Langbein 2012, Dimitrova-Grajzl et al. 2014).

It is possible, however, that judicial workload shapes case duration indirectly, by influencing the timing of court sessions, which in turn affects the timing of settlement. Indeed, when we re-run model (3) of Table 4 while omitting indicator variables for the incidence of court sessions, the coefficient on the variable average caseload per judge is negative and statistically significant (results not reported). To further investigate the role of judicial workload for the procedural dynamics of litigation, we estimate a Cox regression to obtain cause-specific hazards for the incidence of the first court session. The covariates of interest are average total caseload per judge and average number of judicial advisors per judge as a proxy for court resources. We additionally control for variables that are predetermined at the time of filing of the case: the number of disputing parties, the value of stakes in the case, parties' legal form, and the dummies controlling for the year of filing. The results discussed below, however, are robust to inclusion of the full range of case and disputing party controls featured in Table 4.

The estimates summarized in Table 5 confirm our hypothesis about the indirect effect of judicial workload on the timing of settlement via the timing of the first court session. An increase in average caseload per judge all else equal decreases the time to first court session. Based on the 
estimates in Table 5, a one-standard-deviation increase in the average caseload per judge (62 cases, as measured at the case level; see Tables 3 and 2) reduces the hazard rate of the first court session by about $23 \%$. Turning to the other covariates, the time to first court session ceteris paribus decreases with the number of judicial advisors per judge (proxy for court resources) and increases when the case involves multiple parties on either the plaintiff or the defendant side, plausibly because multiplicity of disputing parties renders scheduling of the first court session more difficult. Parties' legal form and stakes exhibit no effect on timing of the first court session.

Finally, for purposes of prediction, Figure 4 displays the estimated cumulative incidence function for settlement in the presence of the competing risk of court judgment. The figure is based on the estimation of the Fine and Gray (1999) model specification analogous to the basic Cox model specification reported in Table 4 while holding covariate values at their means. ${ }^{13}$ The estimated cumulative incidence function is increasing at a decreasing rate. The estimated cumulative probability of settlement at day 300 since filing of the claim is about 0.13 ; at day 600 about 0.23 ; at day 900 about 0.28 ; and at day 1200 about 0.29 .

\section{Conclusion}

A significant proportion of all legal disputes are resolved through settlement. Empirical analyses of the determinants of the timing of settlement, however, are few due to the scarcity of micro data on the duration of disputes. We draw on a novel dataset on the duration of commercial claims filed in Slovenian courts of first instance to study how case duration to settlement varies with stages and features of the litigation process. Using a competing risk regression framework, we find that the time to settlement decreases with disputing parties' participation in events such as court-annexed mediation and the completion of the first court hearing session, both of which

\footnotetext{
${ }^{13}$ The coefficient estimates based on the Fine and Gray (1999) model are, as expected, similar to those based on
} model (1) in Table 4 and are available upon request. 
allow the parties to refine their respective expectations about the case outcome. The positive effect of both mentioned events on settlement hazard, however, gradually diminishes with passage of time since filing of the claim. In contrast, the completion of subsequent court sessions does not affect settlement hazard and, thus, does not reduce the time to settlement.

Judicial workload, interestingly, does not exhibit a direct effect on the timing of settlement, but rather affects the timing of settlement indirectly, through the effect on the timing of the first court hearing session. In terms of policy advice, our results imply that a reduction in average judicial workload would shorten the time to scheduling of the first court hearing session, which based on our findings in turn reduces case duration to settlement.

We further find that case duration to settlement increases with parties' representation through an externally hired attorney or law firm. Consistent with the divergent expectations theories of litigation, case duration to settlement increases when the case is complex; that is, when a judicial advisor is involved in case resolution or when a court expert has been appointed, although the magnitude of the negative effect of expert appointment on settlement hazard diminishes with time since filing of the claim, which increases the prospects that the expert report is completed. Finally, the number of disputing parties, their legal form, and the value of plaintiff's initial claim are not statistically significant predictors of the timing of settlement. 


\section{References}

Andersen, Per Kragh, Ronald B. Geskus, Theo de Witte, and Hein Putter. 2012. "Competing Risks in Epidemiology: Possibilities and Pitfalls." International Journal of Epidemiology, 41, 861-870.

Anderson, James, David Bernstein, and Cheryl Gray. 2005. Judicial Systems in Transition Economies: Assessing the Past, Looking to the Future. The World Bank: The International Bank for Reconstruction and Development.

Ayuso, Mercedes, Lluis Bermudez, and Miguel Santolino. 2015. "The Dynamics of One-Sided Incomplete Information in Motor Disputes." International Review of Law and Economics, 41, 77-85.

Bebchuk, Lucien A. 1984. "Litigation and Settlement Under Imperfect Information." RAND Journal of Economics, 15, 404-415.

Blumenthal, Jeremy A. 2005. "Law and the Emotions: The Problems of Affective Forecasting." Indiana Law Journal, 80:2, 155-238.

Boyd, Christina L. and David A. Hoffman. 2012. "Litigating Toward Settlement." Journal of Law, Economics, and Organization, 29:4, 898-929.

CEPEJ (The European Commission for the Efficiency of Justice). 2014. Report on "European Judicial Systems-Edition 2014 (2012 data): Efficiency and Quality of Justice."

Cleves, Mario, Roberto G. Gutierrez, William Gould, and Yulia V. Marchenko. 2010. An Introduction to Survival Analysis Using Stata, Third Edition. Stata Press, College Station.

Cooter, Robert D. and Daniel L. Rubinfeld. 1994. "An Economic Model of Legal Discovery." Journal of Legal Studies, 23, 435-463.

Cooter, Robert D. and Daniel L. Rubinfeld. 1989. "Economic Analysis of Legal Disputes and Their Resolution." Journal of Economic Literature, 27:3, 1067-1097.

Cox, D.R. 1972. "Regression Models and Life-Tables." Journal of the Royal Statistical Society. Series B (Methodological), 34:2, 187-220.

Cross, Frank B. 2000. "In Praise of Irrational Plaintiffs." Cornell Law Review, 86, 1-32.

Daughety, Andrew F. and Jennifer F. Reinganum. 2012. "Settlement." In: Sanchirico, Chris W. (Ed.), The Encyclopedia of Law and Economics (Second Edition), Ch. 15, Vol. 8 (Procedural Law and Economics). Cheltenham and Camberley: Edward Elgar Publishing Ltd, 386-471.

Daughety, Andrew F. and Jennifer F. Reinganum. 1994. "Settlement Negotiations with TwoSided Asymmetric Information: Model Duality, Information Distribution, and Efficiency." International Review of Law and Economics, 14, 283-298.

Deffains, Bruno and Myriam Doriat. 1999. " The Dynamics of Pretrial Negotiation in France: Is There a Deadline Effect in the French Legal System?" International Review of Law and Economics, 19, 447-470.

Dimitrova-Grajzl, Valentina, Peter Grajzl, and Katarina Zajc. 2014. "Understanding Modes of Civil Case Disposition: Evidence from Slovenian Courts." Journal of Comparative Economics, 42:4, 924-939. 
Dimitrova-Grajzl, Valentina, Peter Grajzl, Janez Sustersic, and Katarina Zajc. 2012. "Court Output, Judicial Staffing, and the Demand for Court Services: Evidence from Slovenian Courts of First Instance." International Review of Law and Economics, 32:1, 19-29.

Doornik, Katherine. 2014. "A Rationale for Mediation and Its Optimal Use." International Review of Law and Economics, 38, 1-10.

Eisenberg, Theodore and Henry S. Farber. 1997. "The Litigious Plaintiff Hypothesis: Case Selection and Resolution." RAND Journal of Economics, 28:0, S92-S112.

Farber, Henry S. and Michelle J. White. 1991. "Medical Malpractice: An Empirical Examination of the Litigation Process." RAND Journal of Economics, 22, 199-217.

Farmer, Amy and Paul Pecorino. 1996. "Issues of Informational Asymmetry in Legal Bargaining." In: Anderson, David A. (Ed.), Dispute Resolution: Bridging the Settlement Gap. Greenwich: JAI Press, 79-105.

Fenn, Paul and Neil Rickman. 2014. "Information and the Disposition of Medical Malpractice Claims: A Competing Risk Analysis." Journal of Law, Economics, and Organization, 30:2, 244-274.

Fournier, Gary M. and Thomas W. Zuehlke. 1996. "The Timing of Out-of-Court Settlements." RAND Journal of Economics, 27:2, 310-321.

Friedman, Daniel and Donald Wittman. 2007. "Litigation with Symmetric Bargaining and TwoSided Incomplete Information." Journal of Law, Economics, and Organization, 23, 98-126.

Galanter, Marc. 2004. "The Vanishing Trial: An Examination of Trials and Related Matters in Federal and State Courts." Journal of Empirical Legal Studies, 1:3, 459-570.

Galič, Aleš. 2014. "(In)compatibility of Procedural Preclusions with the Goals of Civil Justice: An Ongoing Debate in Slovenia." In: Uzelac, Alan (Ed.), Goals of Civil Justice and Civil Procedure in Contemporary Judicial Systems, Ius Gentium: Comparative Perspectives on Law and Justice. Berlin, Heidelberg: Springer, Chapter 11, 221-243.

Galič, Aleš. 2008. "Slovenia." In: Taelman, Piet (Ed.), International Encyclopedia for Civil Procedure. Alphen aan den Rijn: Kluwer Law International.

Galič, Aleš and Christopher Hodges. 2012. "Slovenia." In: Hodges, Christopher, Iris Benöhr, and Naomi Creutzfeld-Banda (Eds.), Consumer ADR in Europe (Civil Justice Systems). Oxford: Hart Publishing, 197-206.

Gould, John P. 1973. "The Economics of Legal Conflicts." Journal of Legal Studies, 2: 279-300.

Grajzl, Peter, Dimitrova-Grajzl, Valentina, and Katarina Zajc. 2015. "Inside Post-Socialist Courts: The Determinants of Adjudicatory Outcomes in Slovenian Commercial Disputes." European Journal of Law and Economics, forthcoming.

Grambsch, Patricia M. and Terry M. Therneau. 1994. "Proportional Hazards Tests and Diagnostics Based on Weighted Residuals." Biometrika, 81:3, 515-526.

Hadfield, Gillian K. 2004. "Where Have all the Trials Gone? Settlements, Non-Trial Adjudications and Statistical Artifacts in the Changing Disposition of Federal Civil Cases." Journal of Empirical Legal Studies, 1:3, 705-734.

Hay, Bruce L. and Kathryn E. Spier. 1998. "Settlement of Litigation." In: The New Palgrave Dictionary of Economics and the Law. London: Macmillan Reference Limited, 442-451. 
Huang, Peter H. and Ho-Mou Wu. 1992. "Emotional Responses in Litigation." International Review of Law and Economics, 12:1, 31-44.

Kaplow, Louis and Steven Shavell. 2002. "Economic Analysis of Law." In: Auerbach, Alan J. and Martin Feldstein (Eds.), Handbook of Public Economics, Vol. III, Amsterdam: North Holland, Chapter 25, 1661-1784.

Kaufmann, Patrick J. and Louis W. Stern. 1988. "Relational Exchange Norms, Perceptions of Unfairness, and Retained Hostility in Commercial Litigation." Journal of Conflict Resolution, 32:3, 534-552.

Kessler, Daniel. 1996. "Institutional Causes of Delay in the Settlement of Legal Disputes." Journal of Law, Economics, and Organization, 12:2, 432-460.

Landes, William M. 1971. "An Economic Analysis of the Courts." Journal of Law and Economics, 14: 61-107.

Langbein, John H. 1985. "The German Advantage in Civil Procedure." The University of Chicago Law Review, 52:4, 823-866.

Langbein, John H. 2012. "The Disappearance of Civil Trial in the United States." Yale Law Review, 122:3, 522-572.

Lurie, Paul M. 2013. "Guided Choice: Early Mediated Settlements and/or Customized Arbitrations." Journal of the American College of Construction Lawyers, 7:2, 167-175.

Nalebuff, Barry J. 1987. "Credible Pretrial Negotiation." RAND Journal of Economics, 18, 198210.

Noordzij, Marlies, Karen Leffondre, Karlijn J. van Stralen, Carmine Zoccali, Friedo W. Dekker, and Kitty J. Jager. 2013. "When Do We Need Competing Risks Methods for Survival Analysis in Nephrology?" Nephrology Dialysis Transplantation, 28: 2670-2677.

Posner, Richard A. 1977. Economic Analysis of Law, Second edition. Boston: Little, Brown and Company.

Priest, George L. and Benjamin Kline. 1984. "The Selection of Disputes for Litigation." Journal of Legal Studies, 13:1, 1-55.

Refo, Patricia Lee. 2004. "The Vanishing Trial." Litigation, 30:2, 1-4.

Schoenfeld, David. 1982. "Partial Residuals for The Proportional Hazards Regression Model." Biometrika, 69:1, 239-241.

Shavell, Steven. 2004. Foundations of Economic Analysis of Law. Cambridge: Belknap Press/Harvard University Press.

Shavell, Steven. 1982. "Suit, Settlement, and Trial: A Theoretical Analysis Under Alternative Methods for the Allocation of Legal Costs." Journal of Legal Studies, 11, 1-2.

Spier, Kathryn E. 1992. "The Dynamics of Pretrial Negotiation." Review of Economic Studies, 59, 93-108.

Spier, Kathryn E. 2007. "Litigation." In: Polinsky, A. Mitchell and Steven Shavell (Eds.), Handbook of Law and Economics, Vol. I. Amsterdam: North Holland, Chapter 4, 259-342.

Spurr, Stephen J. 1997. "The Duration of Litigation." Law and Policy, 19:3, 285-315.

Westeus, Morgan. 2014. "Settlement probability asymmetries in the Swedish Labour Court." European Journal of Law and Economics, 38:3, 485-512. 
Table 1: Descriptive Statistics, Case Duration in Days by Mode of Disposition

\begin{tabular}{lccccc}
\hline Variable & No. Obs. & Mean & Std. Dev. & Min. & Max. \\
\hline Settlement & 240 & 460.8 & 307.8 & 4 & 1407 \\
In-court settlement & 131 & 508.0 & 306.6 & 58 & 1391 \\
Adjourned sine die & 109 & 403.9 & 300.8 & 4 & 1407 \\
Court Judgment & 324 & 591.4 & 314.8 & 6 & 1559 \\
Trial-based judgment & 295 & 621.2 & 308.1 & 6 & 1559 \\
Default judgment & 27 & 302.6 & 231.1 & 86 & 1179 \\
Judgment on admission & 1 & 182.0 & n.a. & 182 & 182 \\
Judgment of nolle prosequi & 5 & 470.0 & 300.4 & 104 & 865 \\
Disposed via Any Means & 564 & 536.2 & 318.2 & 4 & 1559 \\
\hline
\end{tabular}


Table 2: Variable Definitions and Source

\begin{tabular}{|c|c|c|}
\hline Variable & Description & Source \\
\hline Settlement & Case duration from filing to settlement (broadly defined), in days. & Collected from case files \\
\hline \multicolumn{3}{|l|}{ Discrete time-varying covariates } \\
\hline 1st Court Session & Dummy equal to 1 if first court session has been completed. & Collected from case files \\
\hline 2nd Court Session & Dummy equal to 1 if second court session has been completed. & Collected from case files \\
\hline 3rd Court Session & Dummy equal to 1 if third court session has been completed. & Collected from case files \\
\hline 4th Court Session & Dummy equal to 1 if fourth court session has been completed. & Collected from case files \\
\hline 5th Court Session & Dummy equal to 1 if fifth court session has been completed. & Collected from case files \\
\hline \multicolumn{3}{|l|}{ Time-invariant covariates } \\
\hline \multicolumn{3}{|l|}{ Case characteristics } \\
\hline Mediation & Dummy equal to 1 if court-annexed mediation was introduced in the process of case adjudication. & Collected from case files \\
\hline Court Expert & Dummy equal to 1 if court expert was involved in adjudication of the case. & Collected from case files \\
\hline Judicial Advisor & Dummy equal to 1 if a judicial advisor was involved in adjudication of the case. & Collected from case files \\
\hline$>1$ Judge & Dummy equal to 1 if more than one judge was in charge of the case. & Collected from case files \\
\hline Stakes & Plaintiff's initial claim as stipulated in the lawsuit, in EUR 100,000. & Collected from case files \\
\hline \multicolumn{3}{|l|}{ Number of parties } \\
\hline$>1$ Plaintiff or Defendant & Dummy equal to 1 if case involves either more than one plaintiff or more than one defendant. & Collected from case files \\
\hline \multicolumn{3}{|l|}{ Parties' legal form } \\
\hline$\geq 1$ Sole Trader Enterprise & Dummy equal to 1 if at least one party is a sole trader enterprise. & Collected from case files \\
\hline$\geq 1$ Physical Person & Dummy equal to 1 if at least one party is a physical person. & Collected from case files \\
\hline$\geq 1$ Municipality & Dummy equal to 1 if at least one party is a municipality. & Collected from case files \\
\hline$\geq 1$ Public or Government & Dummy equal to 1 if at least one party is a legal entity in public interest or a government entity. & Collected from case files \\
\hline$\geq 1$ Foreign & Dummy equal to 1 if at least one party is a foreign entity. & Collected from case files \\
\hline \multicolumn{3}{|l|}{ Parties' representation } \\
\hline$\geq 1$ Public Prosecutor & Dummy equal to 1 if at least one party is represented by the public prosecutor office. & Collected from case files \\
\hline$\geq 1$ Self or Plenipotentiary & $\begin{array}{l}\text { Dummy equal to } 1 \text { if at least one party is either self-represented or represented by a plenipotentiary that is } \\
\text { not an attorney or a law firm. }\end{array}$ & Collected from case files \\
\hline \multicolumn{3}{|c|}{ (1) } \\
\hline Avg. Caseload per Judge & $\begin{array}{l}\text { Average total caseload per judge (total court caseload divided by the number of serving judges) at the court } \\
\text { where the case was adjudicated in the year when the case was filed. }\end{array}$ & Official court statistics \\
\hline Avg. Judicial Advisors per Judge & $\begin{array}{l}\text { Average number of judicial advisors per judge (total judicial advisors at the court divided by the number of } \\
\text { serving judges) at the court where the case was adjudicated in the year when the case was filed. }\end{array}$ & Official court statistics \\
\hline
\end{tabular}


Table 3: Descriptive Statistics, Time-Invariant Covariates

\begin{tabular}{|c|c|c|c|c|c|}
\hline Variable & No. Obs. & Mean & Std. Dev. & Min. & Max. \\
\hline \multicolumn{6}{|l|}{ Case characteristics } \\
\hline Mediation & 662 & 0.119 & 0.324 & 0 & 1 \\
\hline Court Expert & 662 & 0.101 & 0.302 & 0 & 1 \\
\hline Judicial Advisor & 662 & 0.192 & 0.394 & 0 & 1 \\
\hline$>1$ Judge & 662 & 0.302 & 0.460 & 0 & 1 \\
\hline Stakes (in EUR 100,000) & 662 & 8.750 & 90.149 & 0.007 & 2101.0 \\
\hline \multicolumn{6}{|l|}{ Number of parties } \\
\hline$>1$ Plaintiff or Defendant & 662 & 0.178 & 0.383 & 0 & 1 \\
\hline \multicolumn{6}{|l|}{ Parties' legal form } \\
\hline$\geq 1$ Sole Trader Enterprise & 662 & 0.140 & 0.348 & 0 & 1 \\
\hline$\geq 1$ Physical Person & 662 & 0.124 & 0.330 & 0 & 1 \\
\hline$\geq 1$ Municipality & 662 & 0.051 & 0.221 & 0 & 1 \\
\hline$\geq 1$ Public or Government & 662 & 0.289 & 0.453 & 0 & 1 \\
\hline$\geq 1$ Foreign & 662 & 0.080 & 0.272 & 0 & 1 \\
\hline \multicolumn{6}{|l|}{ Parties' representation } \\
\hline$\geq 1$ Public Prosecutor & 662 & 0.056 & 0.230 & 0 & 1 \\
\hline$\geq 1$ Self or Plenipotentiary & 662 & 0.515 & 0.500 & 0 & 1 \\
\hline \multicolumn{6}{|l|}{ Court characteristics } \\
\hline Avg. Caseload per Judge & 662 & 689.6 & 61.7 & 586.9 & 798.3 \\
\hline Avg. Judicial Advisors per Judge & 662 & 0.54 & 0.16 & 0.29 & 0.80 \\
\hline
\end{tabular}


Table 4: Regression Results, Settlement Hazard

\begin{tabular}{|c|c|c|c|c|c|c|}
\hline \multirow[b]{2}{*}{ Explanatory variables } & \multicolumn{2}{|c|}{ Model (1) } & \multicolumn{2}{|c|}{ Model (2) } & \multicolumn{2}{|c|}{ Model (3) } \\
\hline & Coeff. & Std. Error & Coeff. & Std. Error & Coeff. & Std. Error \\
\hline \multicolumn{7}{|l|}{ Discrete time-varying } \\
\hline 1st Court Session & $2.415^{* * *}$ & $(0.213)$ & $3.205^{* * *}$ & $(0.336)$ & $3.238 * * *$ & $(0.323)$ \\
\hline 2nd Court Session & -0.357 & $(0.241)$ & -0.304 & $(0.243)$ & -0.344 & $(0.247)$ \\
\hline 3rd Court Session & -0.187 & $(0.377)$ & -0.240 & $(0.381)$ & -0.181 & $(0.383)$ \\
\hline 4th Court Session & 0.297 & $(0.596)$ & 0.235 & $(0.611)$ & 0.308 & $(0.614)$ \\
\hline 5th Court Session & -1.156 & (1.104) & -1.384 & (1.165) & -1.317 & (1.156) \\
\hline \multicolumn{7}{|l|}{ Continuous time-varying } \\
\hline 1st Court Session $\times t$ & & & $-0.002 * * *$ & $(0.001)$ & $-0.002 * * *$ & $(0.001)$ \\
\hline Mediation $\times t$ & & & $-0.002 * * *$ & $(0.001)$ & $-0.002 * * *$ & $(0.001)$ \\
\hline Court Expert $\times t$ & & & $0.004 * * *$ & $(0.001)$ & $0.004 * * *$ & $(0.001)$ \\
\hline \multicolumn{7}{|l|}{ Time-invariant } \\
\hline \multicolumn{7}{|l|}{ Case characteristics } \\
\hline Mediation & $0.840 * * *$ & $(0.197)$ & $1.597 * * *$ & $(0.276)$ & $1.623 * * *$ & $(0.274)$ \\
\hline Court Expert & $-2.023 * * *$ & $(0.333)$ & $-4.365 * * *$ & $(0.656)$ & $-4.453 * * *$ & $(0.658)$ \\
\hline Judicial Advisor & $-0.555^{* *}$ & $(0.266)$ & $-0.524 * *$ & $(0.267)$ & $-0.444 * *$ & $(0.220)$ \\
\hline$>1$ Judge & -0.178 & $(0.175)$ & -0.148 & $(0.175)$ & -0.115 & $(0.172)$ \\
\hline Stakes (in EUR 100,000) & -0.029 & $(0.019)$ & -0.030 & $(0.021)$ & -0.031 & $(0.021)$ \\
\hline \multicolumn{7}{|l|}{ Number of parties } \\
\hline >1 Plaintiff or Defendant & -0.408 & $(0.255)$ & -0.350 & $(0.254)$ & -0.347 & $(0.244)$ \\
\hline \multicolumn{7}{|l|}{ Parties' legal form } \\
\hline$\geq 1$ Sole Trader Enterprise & $0.337 *$ & $(0.187)$ & 0.283 & $(0.190)$ & 0.187 & $(0.198)$ \\
\hline$\geq 1$ Physical Person & -0.161 & $(0.367)$ & -0.202 & $(0.364)$ & -0.207 & $(0.348)$ \\
\hline$\geq 1$ Municipality & -0.392 & $(0.454)$ & -0.271 & $(0.460)$ & -0.244 & $(0.392)$ \\
\hline$\geq 1$ Public or Government & -0.074 & $(0.178)$ & -0.113 & $(0.177)$ & -0.111 & $(0.173)$ \\
\hline$\geq 1$ Foreign & -0.366 & $(0.359)$ & -0.371 & $(0.355)$ & -0.324 & $(0.327)$ \\
\hline \multicolumn{7}{|l|}{ Parties' representation } \\
\hline$\geq 1$ Public Prosecutor & -0.710 & $(0.522)$ & -0.653 & $(0.528)$ & -0.629 & $(0.513)$ \\
\hline$\geq 1$ Self or Plenipotentiary & $0.748 * * *$ & $(0.180)$ & $0.767 * * *$ & $(0.178)$ & $0.757 * * *$ & $(0.176)$ \\
\hline \multicolumn{7}{|l|}{ Court characteristics } \\
\hline Avg. Caseload per Judge & & & & & -0.001 & $(0.001)$ \\
\hline Avg. Judicial Advisors per Judge & & & & & 0.435 & $(0.603)$ \\
\hline \multicolumn{7}{|l|}{ Fixed effects } \\
\hline Year FE & \multicolumn{2}{|c|}{ Yes } & \multicolumn{2}{|c|}{ Yes } & \multicolumn{2}{|c|}{ Yes } \\
\hline Court FE & \multicolumn{2}{|c|}{ Yes } & \multicolumn{2}{|c|}{ Yes } & \multicolumn{2}{|c|}{ No } \\
\hline Observations & \multicolumn{2}{|c|}{1,762} & \multicolumn{2}{|c|}{1,762} & \multicolumn{2}{|c|}{1,762} \\
\hline Cases & \multicolumn{2}{|c|}{662} & \multicolumn{2}{|c|}{662} & \multicolumn{2}{|c|}{662} \\
\hline Failures via settlement & \multicolumn{2}{|c|}{240} & & & 24 & \\
\hline Censored & & & & & 42 & \\
\hline
\end{tabular}

Notes: The table present coefficient estimates and their standard errors based on Cox regression models of settlement hazard where competing risk events are treated as right-censored observations. The omitted category for parties' legal form is all parties are companies. The omitted category for parties' representation is all parties are represented by an attorney or a law firm. Reported standard errors are heteroskedasticity-robust and clustered at the case level. *, **, and *** indicate significance at the $10 \%, 5 \%$, and $1 \%$ levels, respectively. 
Table 5: Regression Results, First Court Session Hazard

\begin{tabular}{|c|c|c|}
\hline Explanatory variables & Coeff. & Std. Error \\
\hline \multicolumn{3}{|l|}{ Court characteristics } \\
\hline Avg. Caseload per Judge & $-0.004^{* * *}$ & $(0.001)$ \\
\hline Avg. Judicial Advisors per Judge & $0.920 * *$ & $(0.390)$ \\
\hline \multicolumn{3}{|l|}{ Case characteristics } \\
\hline Stakes (in EUR 100,000) & -0.000 & $(0.001)$ \\
\hline \multicolumn{3}{|l|}{ Number of parties } \\
\hline$>1$ Plaintiff or Defendant & $-0.565 * * *$ & $(0.145)$ \\
\hline \multicolumn{3}{|l|}{ Parties' legal form } \\
\hline$\geq 1$ Sole Trader Enterprise & 0.023 & $(0.135)$ \\
\hline$\geq 1$ Physical Person & 0.241 & $(0.167)$ \\
\hline$\geq 1$ Municipality & 0.099 & $(0.172)$ \\
\hline$\geq 1$ Public or Government & 0.073 & $(0.097)$ \\
\hline$\geq 1$ Foreign & 0.027 & $(0.154)$ \\
\hline Year FE & \multicolumn{2}{|c|}{ Yes } \\
\hline Observations & \multicolumn{2}{|c|}{686} \\
\hline Cases & \multicolumn{2}{|c|}{661} \\
\hline Failures via first court session & \multicolumn{2}{|c|}{496} \\
\hline Censored & \multicolumn{2}{|c|}{165} \\
\hline \multicolumn{3}{|c|}{$\begin{array}{l}\text { Notes: The table presents coefficient estimates and their standard errors } \\
\text { based on Cox regression model of first court session hazard where } \\
\text { competing risk events are treated as right-censored observations. The } \\
\text { omitted category for parties' legal form is all parties are companies. } \\
\text { Reported standard errors are heteroskedasticity-robust and clustered at } \\
\text { the case level. *, **, and } * * * \text { indicate significance at the } 10 \%, 5 \% \text {, and } \\
1 \% \text { levels, respectively. }\end{array}$} \\
\hline
\end{tabular}


Figure 1: Case Duration to Settlement

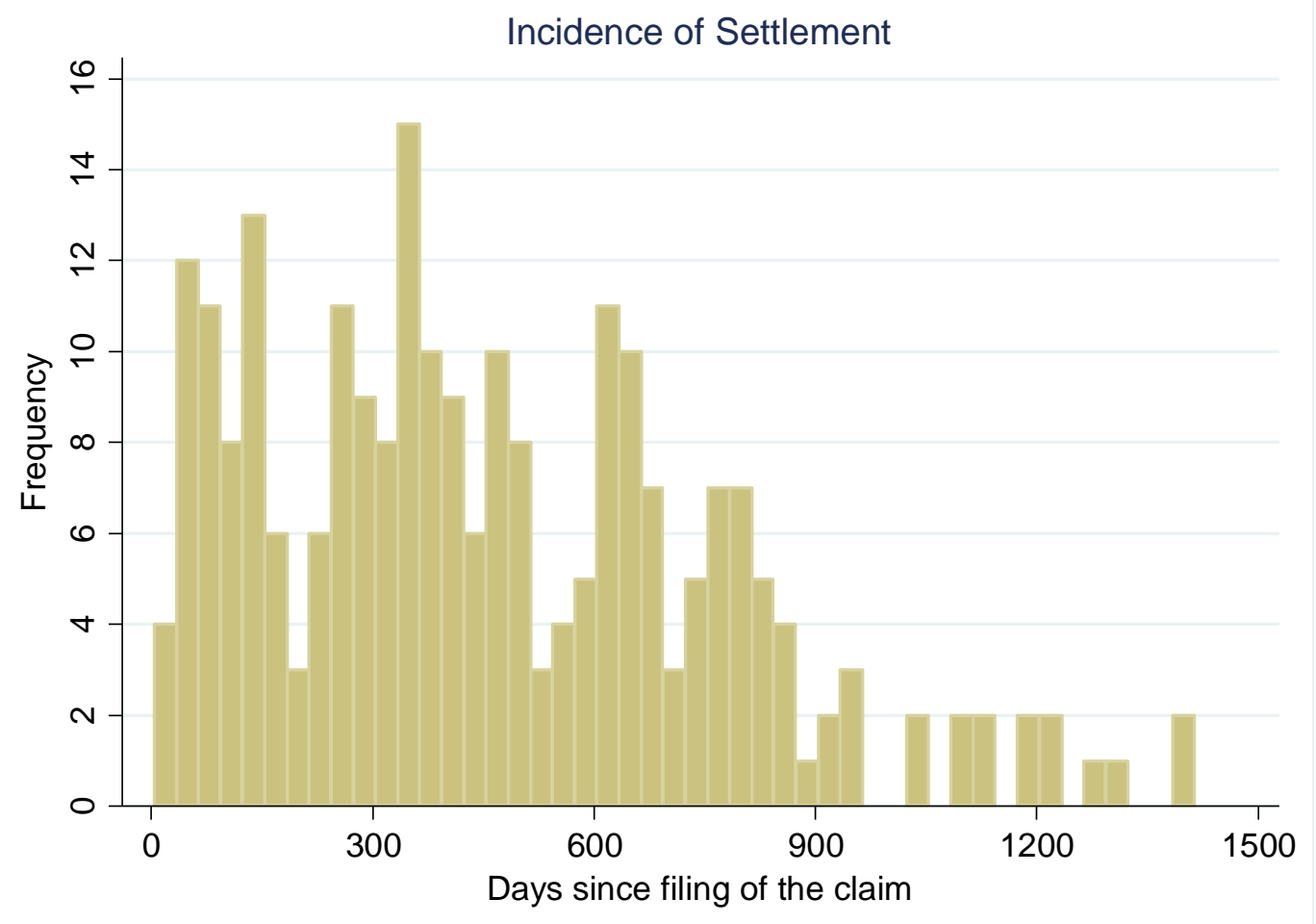


Figure 2: Non-Parametric Hazard Ratio Estimate for Settlement

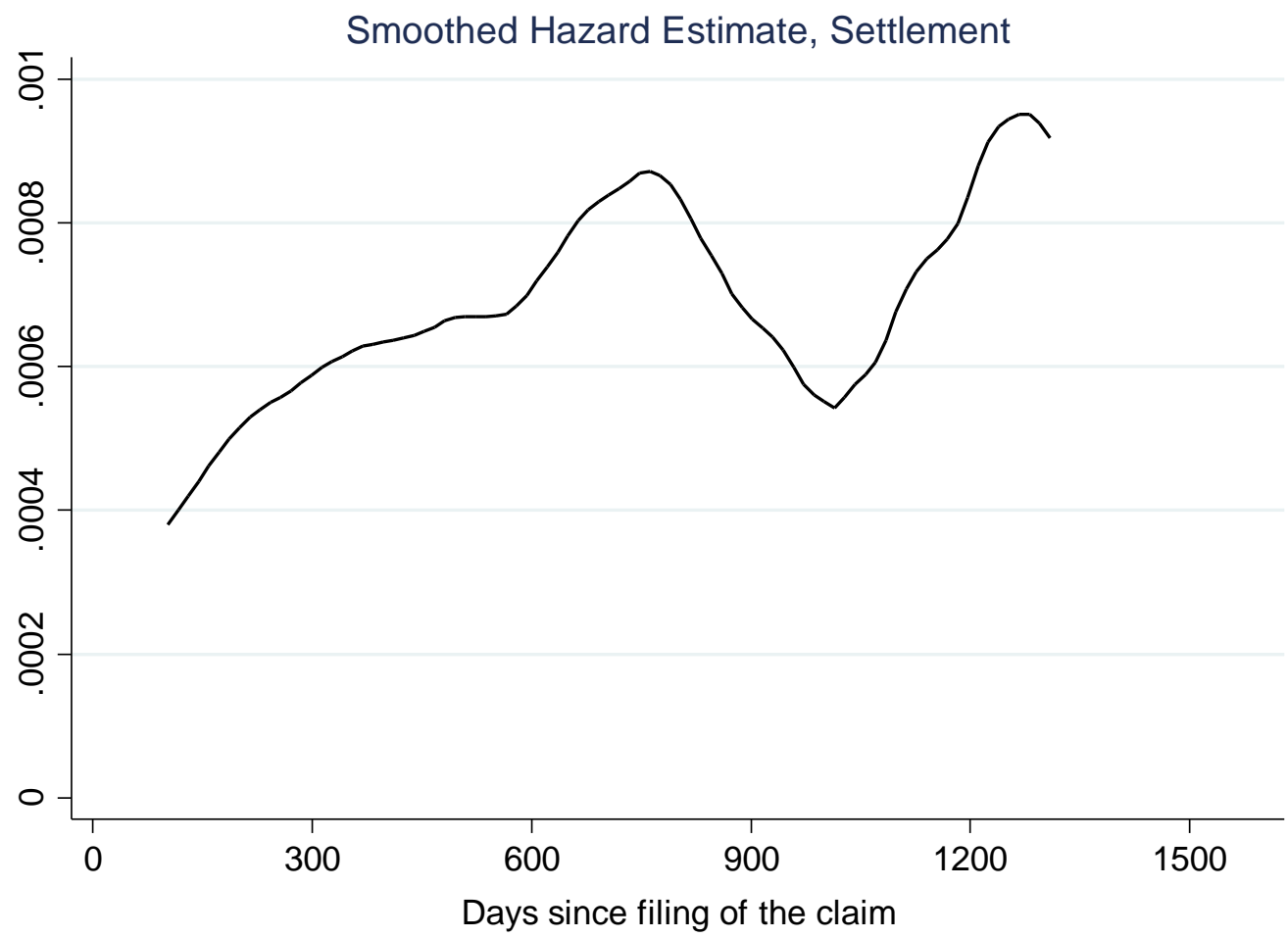


Figure 3: Timing of Court Sessions
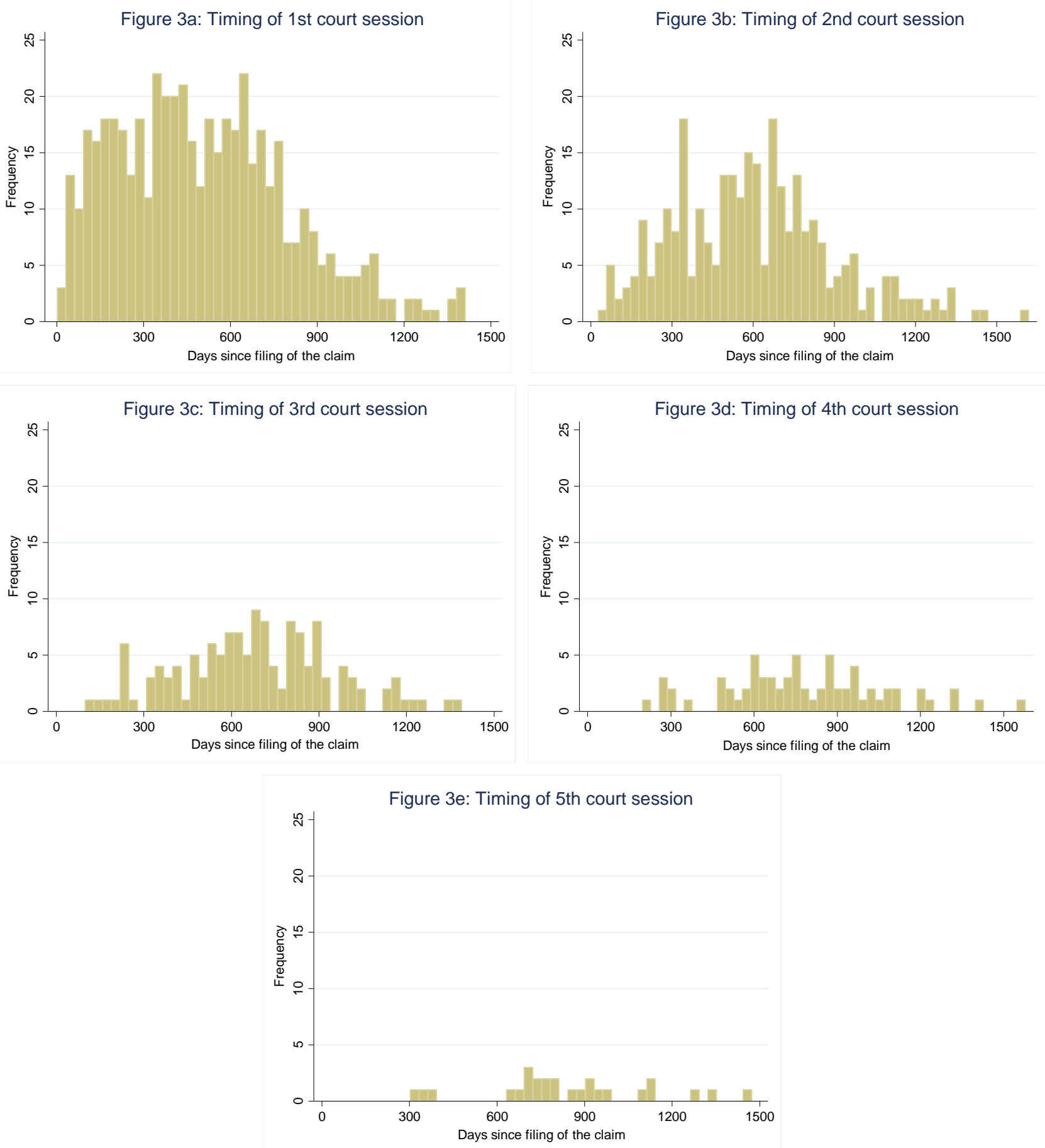
Figure 4: Cumulative Incidence Function for Settlement

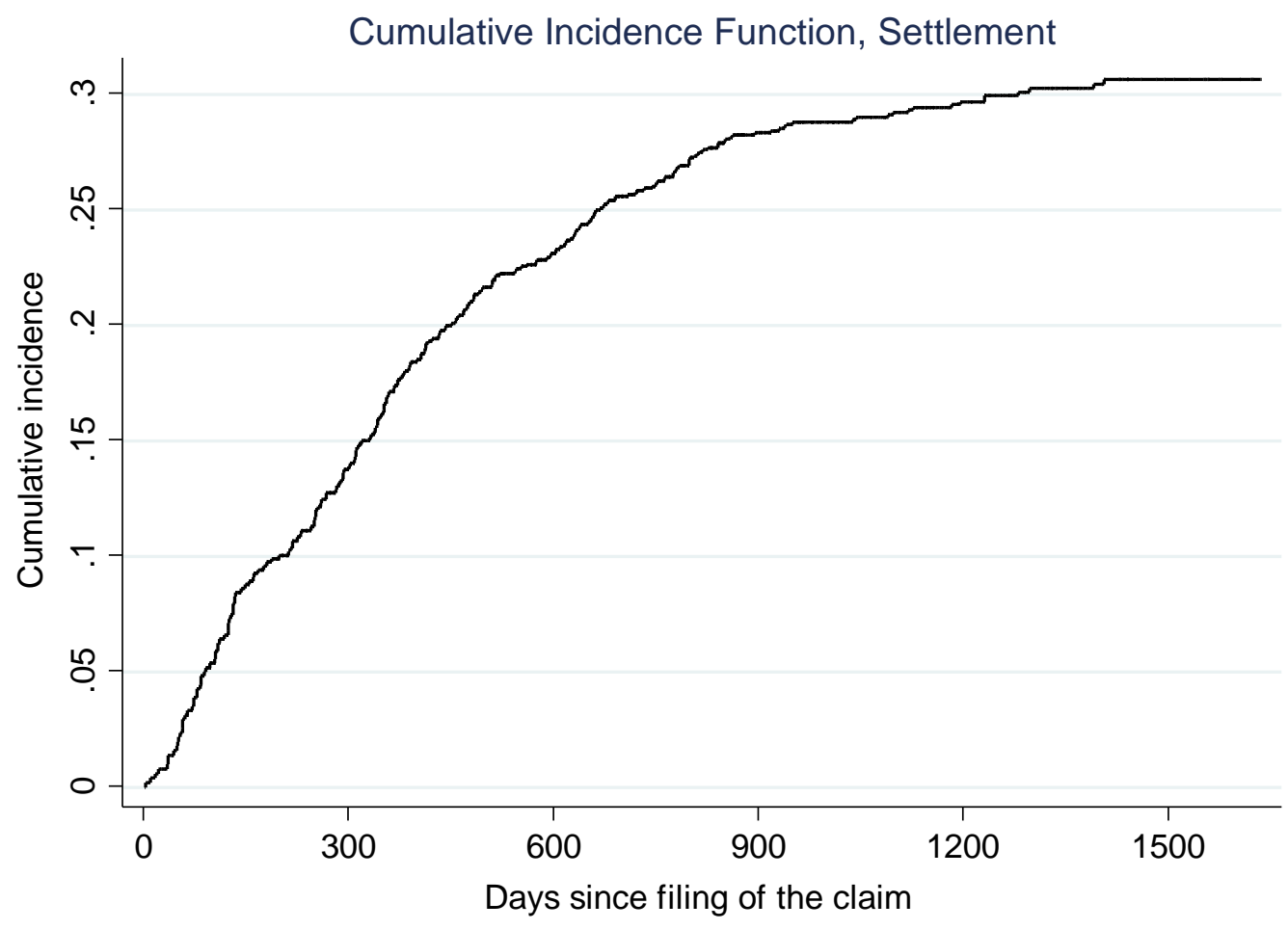

